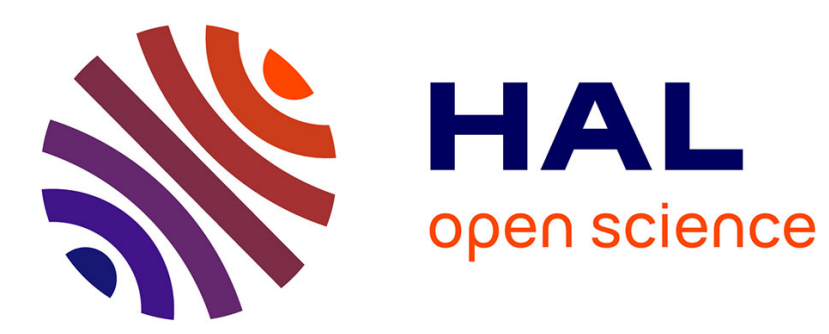

\title{
New radiolarian assemblages from La Desirade Island basement complex (Guadeloupe, Lesser Antilles arc) and Caribbean tectonic implications
}

Fabrice Cordey, Jean-Jacques Cornee

\section{- To cite this version:}

Fabrice Cordey, Jean-Jacques Cornee. New radiolarian assemblages from La Desirade Island basement complex (Guadeloupe, Lesser Antilles arc) and Caribbean tectonic implications. Bulletin de la Société Géologique de France, 2009, 180 (5), pp.399-409. 10.2113/gssgfbull.180.5.399 hal-03275251

\section{HAL Id: hal-03275251 \\ https://hal.science/hal-03275251}

Submitted on 30 Jun 2021

HAL is a multi-disciplinary open access archive for the deposit and dissemination of scientific research documents, whether they are published or not. The documents may come from teaching and research institutions in France or abroad, or from public or private research centers.
L'archive ouverte pluridisciplinaire HAL, est destinée au dépôt et à la diffusion de documents scientifiques de niveau recherche, publiés ou non, émanant des établissements d'enseignement et de recherche français ou étrangers, des laboratoires publics ou privés. 
New radiolarian assemblages from La Désirade Island basement complex (Guadeloupe, Lesser Antilles Arc) and Caribbean tectonic implications

Fabrice Cordey ${ }^{1} \&$ Jean-Jacques Cornée ${ }^{2}$

Key words : Radiolaria, La Désirade, Guadeloupe, Lesser Antilles, Caribbean plate, Jurassic

${ }^{1}$ Université Lyon 1, UMR 5125 Paléoenvironnement et Paléobiosphère, 2 rue Raphaël Dubois, 69622 Villeurbanne cedex, France; fabrice.cordey@univ-lyon1.fr

${ }^{2}$ Université Montpellier 2, INSU-CNRS, Laboratoire Géosciences Montpellier, place E.

Bataillon, 34095 Montpellier, France; jean-jacques.cornee@gm.univ-montp2.fr 


\section{Abstract}

New radiolarian assemblages of Late Jurassic age were extracted from seven chert localities of the basement complex of La Désirade Island (Guadeloupe), the oldest geological unit of the Lesser Antilles Arc and the eastern Caribbean region. These fauna range in age from Kimmeridgian or early Tithonian to early or early late Tithonian, showing that La Désirade cherts are not all coeval, contrary to what was established by previous studies. Furthermore, the close spatial association of cherts and volcanic elements composed of basaltic flows and volcaniclastics suggests a mixed setting of hydrothermal siliceous deposits and biogenous sedimentation consistent with an arc-related oceanic setting rather than an ophiolite-type oceanic crust. As the youngest age is obtained to the northwest of the basement complex whereas older data are found to the southeast, it also suggests that La Désirade basement complex may have undergone some structural stacking consistent with an accretion-type geodynamic setting. Our biochronological data provide a preliminary tectonic model of an eastward subduction zone for Lesser Antilles arc basement emplacement during the Mesozoic. 


\section{Nouveaux assemblages de radiolaires du complexe de base de La Désirade (Guadeloupe, Petites Antilles) et implications tectoniques caraïbes}

Mots-clés : Radiolaria, La Désirade, Guadeloupe, Petites Antilles, plaque Caraïbe, Jurassique

\section{Résumé}

De nouveaux assemblages de radiolaires d’âge Jurassique supérieur sont extraits de sept localités de jaspes siliceux associés au complexe de base de l'île de La Désirade (archipel de Guadeloupe), l'unité géologique la plus ancienne de l'arc des petites Antilles et de la région est-caraïbe. Ces faunes ont un âge qui s'étend du Kimméridgien supérieur-Tithonien inférieur au Tithonien inférieur-Tithonien supérieur basal montrant que, contrairement à ce qui avait été établi précédemment, les sédiments océaniques de La Désirade sont diachrones. Par ailleurs, l'association très particulière des jaspes à radiolaires et des éléments volcaniques du complexe de base suggère l'existence d'une sédimentation siliceuse hydrothermale associée à des dépôts biogènes dans un contexte de sédimentation océanique d'arc plutôt que de dépôts sur une croûte océanique vraie. Nos résultats suggèrent que le complexe de base de La Désirade a subit un raccourcissement tectonique du nord-ouest au sud-est, compatible avec une structuration de complexe d'accrétion associé à une subduction vers l'est, fournissant un modèle préliminaire de mise-en-place tectonique de ce segment de l'arc des Antilles au Mésozoïque. 


\section{INTRODUCTION}

The scope of this study is to reassess the age and significance of La Désirade Island oceanic sediments and associated volcanic rocks belonging to the Lesser Antilles arc basement (fig. 1). The geodynamic history and plate tectonic evolution of the Caribbean region have been a subject of intense debate for over 40 years, due to the complexity of its elements and their protracted history. This region evolved at the interaction between two major continents (North and South Americas) and two major oceans (Pacific and Atlantic) since the Jurassic, and consequently comprises oceanic rocks of various settings (ophiolites, arcs, back-arcs, accretion complexes). The island of La Désirade is an important element of this Caribbean network of Jurassic oceanic rocks, being the easternmost element of the Lesser Antilles island arc (fig. 2). Furthermore, it is the only element of the Lesser Antilles region exposing Mesozoic crystalline basement. It has generated a great deal of attention since Fink [1968] determined a Late Jurassic radiometric age for a trondhjemite locality whereas the oldest age of the Lesser Antilles was thought to be much younger. The actual nature of the basal complex of La Désirade Island has been much debated and no final model has yet been established with certainty [see recent discussion by Mattinson et al., 2008]. To summarize, it has been considered as part of an ophiolitic complex made of oceanic crust [Mattinson et al., 1973, 1980; Fox \& Heezen, 1975; Dinkelman \& Brown; 1977; Le Guen de Kerneizon et al.; 1979], or a primitive island arc subsequently detached from the Greater Antilles [Fink, 1968, 1970a, 1970b, 1972; Bouysse et al., 1983; Donnelly et al., 1990, Gauchat, 2004]. More recently, Mattinson \& Hopson [in Mattinson et al., 2008] stood by their original conclusion that the igneous rock assemblage and vertical distribution on La Désirade Island and its submerged foundation are compatible with the upper part of an ophiolite. 
Radiolarian-bearing cherts from La Désirade have previously been studied and dated by Bouysse et al. [1983], Montgomery et al. [1992] and Mattinson et al. [2008]. Radiolarians extracted from these rocks have not only been used for biochronology but also for biogeography in order to assess the former location and the tectonic origin of the Caribbean plate [Montgomery et al., 1992, 1994a, 1994b]. However, one problem with former studies is that radiolarian ages provided by Bouysse et al. [1983] and Montgomery et al. [1992] are not equivalent (Early Cretaceous vs. Late Jurassic, respectively). In order to reassess their age in the light of updated radiolarian biozonations, we undertook a new investigation using field and laboratory techniques previously applied to Cordilleran chert terranes [Cordey \& Krauss, 1990]. As a result, we present new micropaleontological and biostratigraphic data from La Désirade cherts combined with new field observations. These results provide some new constraints on the nature of La Désirade oldest rocks and therefore on the preliminary tectonic evolution of the Lesser Antilles and the eastern Caribbean region.

\section{GEOLOGICAL SETTING}

\section{La Désirade Island}

La Désirade is a $10 \mathrm{~km}$ long island located to the east of the main island of Guadeloupe (fig. 2), standing out in the forearc of the Lesser Antilles region. The western part of the Guadeloupe archipelago is a segment of the active Plio-Quaternary arc currently represented by the volcano "La Soufrière". The eastern part of the Guadeloupe archipelago is composed of Grande Terre, Marie-Galante, and La Désirade, which all belong to the Calcareous Lesser Antilles ("Petites Antilles calcaires"). These islands correspond to eroded fragments of an Eocene-Miocene arc capped by Plio-Quaternary calcareous formations, showing that the activity of the Lesser Antilles arc has shifted to the west since the Eocene-Miocene (fig. 2). La Désirade Island is 
bounded to the northeast by a trench $4000 \mathrm{~m}$ deep, one major escarpment of the eastern Caribbean plate topographic features.

Field studies and geological mapping of the island were originally undertaken by Fink [1970b] and then Westercamp [1980], leading to the differentiation of three units by Bouysse et al. [1983]:

1) a Central Acid Massif composed of felsic quartz-diorite intrusion associated with rhyolitic lava flows;

2) a Northeast Volcanic Complex comprising pillowed metabasalt and interbedded radiolarian chert;

3) an Upper Meta-andesitic group represented by east-west trending dike swarm complex.

Mattinson et al. [2008] have kept Unit 2 of Bouysse et al. [1983] but have renamed the first and third units the Trondhjemitic/Rhyolitic Igneous Complex and the Diabasic/Microdioritic Dike Swarm, respectively. Bouysse et al. [1983] interpreted the trondhjemite/rhyolite assemblage to be the oldest on the island as shown by a Late Jurassic radiometric age ( $\sim 145$ Ma, Fink, 1968; Mattinson et al., 1973, 1980] and considered that their unit 2 was younger as shown by a single locality of Early Cretaceous radiolarians (Hauterivian-Barremian). This micropaleontological datum has since been rightfully questioned by Montgomery et al. [1992] who reported five radiolarian assemblages of Late Jurassic age (mid late Tithonian). These radiolarian data have recently been documented again by Mattinson et al. [2008] who also produced a new radiometric age of $143.74+/-0.33$ Ma using CA-TIMS zircon method.

\section{La Désirade cherts}

They are exposed within the Northeast Volcanic complex of Bouysse et al. [1983] (fig. 3) and are found in various settings (fig. 4): 1) bedded sequence within pillow basaltic flows, locally duplicated, 2) inter- and intra-pillow fillings, 3) thin layers in volcaniclastics. Fink [1970b] first 
implied that radiolarian cherts occur within basalts but also overlie them. This interpretation was recently revised by Mattinson et al. [2008] who consider that "the sedimentary rocks occur within the submarine lavas, not on top of them". In their opinion, radiolarian cherts from La Désirade Island are not equivalent to typical radiolarian ribbon chert (RRC) usually composed of rhythmically bedded deposits in which thin chert layers are separated by shaly partings, a feature amplified with diagenesis. Instead, they consider these cherts as intralava sediments derived from heating, oxidation and silicification of initially porous ferruginous hydrothermal sediment when they were buried beneath hot new submarine flows. To support their view, Mattinson et al. [2008] state that "radiolarians are sparse and commonly absent from the red cherts".

\section{BIOSTRATIGRAPHIC RESULTS}

\section{Chert localities, faunal assemblages and ages}

On the island of La Désirade, chert exposures are essentially found: 1) on cliffs or on the shore between Baie Mahault and Pointe du Grand Abaque (fig. 3), more particularly around Pointe Doublé and Pointe Mancenillier; 2) in small outcrops on topographic knobs located between Baie Mahault and Pointe Mancenillier (fig. 3); these knobs are broadly aligned in a SW-NE direction.

Seven radiolarian localities have yielded diagnostic radiolarians (pl. 1, 2). Some morphotypes are identical to some documented by Bouysse et al. [1983], Montgomery et al. [1992] and Mattinson et al. [2008]. However these studies do not provide any fossil location in coordinates, preventing precise geographic correlations. A complete list of radiolarian morphotypes obtained during this study is presented in Table 1 . The following descriptions include details on chert exposures, microfossil content and biochronological assignments. The 
nature and composition of our radiolarian assemblages led us to use Baumgartner et al. [1995] biozonation, but we also took into account other biochronological data from North America [Pessagno et al., 1984, 1993], Asia [Matsuoka, 1995a; Matsuoka et al., 2002], and Tethys [Gorican, 1994].

LDE3 (coordinates N16²0’02.2” W61 00'11.8”; bedding orientation and dip N078.05W) (fig. 3): at the base of cliff, $30 \mathrm{~cm}$ thick red/mauve chert sequence between masses of basalts (layers or pillows); it comprises five chert beds with thin red and green shale interlayers; sequence exposed over about $60 \mathrm{~m}$ along the shore. Radiolarians from this locality are badly preserved. Only Vallupus sp. was identified, indicating a Late Jurassic age (Kimmeridgian or Tithonian).

LDE7 (coordinates N16 $19 ' 56.2^{\prime \prime}$ W61 $00 ' 19.4$ ”; bedding orientation and dip N120.30NE) (fig. 3): located on the shore below the lighthouse, $50 \mathrm{~cm}$ thick red chert sequence with one isolated basalt pillow. Occurring radiolarians are Eucyrtidiellum ptyctum (Riedel \& Sanfilippo), Obesacapsula verbana (Parona) and Praeconocaryomma sp.. This association was not identified previously on the island [Bouysse et al. 1983, Montgomery et al. 1992, Mattinson et al. 2008]. It is not easily correlated with the zonation proposed by E.A. Pessagno Jr. [see Mattinson et al. 2008 and references therein). However, the two species Obesacapsula verbana and Eucyrtidiellum ptyctum are present in UAZ11 of Baumgartner et al. [1995] zonation, providing a late Kimmeridgian or early Tithonian age.

LDE9 (coordinates N16 $19^{\prime} 44.1^{\prime \prime}$ W61 ${ }^{\circ} 00^{\prime} 41.3^{\prime \prime}$ ) (fig. 3); $790 \mathrm{~m}$ to the southwest of the lighthouse, small outcrop of red chert with no clear relationships with basalts. Radiolarians comprise Archaeodictyomitra excellens (Tan), Archaeodictyomitra minoensis (Mizutani), Eucyrtidiellum sp., Loopus primitivus (Matsuoka \& Yao), and Pseudodictyomitra carpatica 
(Lozynyak). Again, this assemblage was not found previously on the island, and can be assigned to UAZ11-12 of Baumgartner et al. [1995]. The corresponding time interval ranges from the late Kimmeridgian to the early late Tithonian.

LDE12 (coordinates N16²0’00.7” W61 00 '35.6”; bedding orientation and dip N002.45E) (fig. 3); $440 \mathrm{~m}$ to the northwest of lighthouse, 50 to $80 \mathrm{~cm}$ thick chert sequence on a topographic knob; red to dark red chert beds of variable thicknesses. This locality yields a well-preserved radiolarian association comprising Archaedictyomitra sp. aff. excellens (Tan), Archaeodictyomitra minoensis (Mizutani), Archaedictyomitra sp., Emiluvia sp. cf. salensis Foreman, Eucyrtidiellum pyramis (Aita), Loopus primitivus (Matsuoka \& Yao), Pseudodictyomitra carpatica (Lozyniak), Pseudodictyomitra sp., Pseudodictyomitrella sp. aff. tuscanica (Chiari, Cortese \& Marcucci), Sethocapsa sp., Stichocapsa sp., ?Stylocapsa sp., Williriedellum sp., Xitus gifuensis Mizutani and Zhamoidellum sp. aff. ovum Dumitrica. This assemblage contains some morphotypes from Tibet and Japan presented by Matsuoka et al. [2002; 2005] belonging to their Pseudodictyomitra carpatica biozone. For instance, our Pseudodictyomitrella sp. aff. tuscanica (Chiari, Cortese \& Marcucci) (pl. 2, fig. 11) closely resembles the specimens from Shirokawa area (southwest Japan) illustrated by Matsuoka et al. [2005; fig. $\left.5, \mathrm{n}^{\circ} 7\right]$ and attributed by these authors to Stichocapsa praepulchella Hori, a probable junior synonym of Pseudodictyomitrella tuscanica (Chiari, Cortese \& Marcucci) (see Chiari et al. [1997] and Hori [1999]). Overall, this assemblage can be assigned to UAZ12 [Baumgartner et al., 1995] of early to early late Tithonian age.

LDE22 (coordinates N16²0’12.8” W61 ${ }^{\circ} 00^{\prime} 13.5^{\prime}$; bedding orientation and dip N100.30NE) (fig. 3); $230 \mathrm{~m}$ to the northeast of the meteorological station building, 30 to $100 \mathrm{~cm}$ thick red chert sequence with 'chevron' folds. This locality has a fairly well-preserved radiolarian 
association comprising Emiluvia chica Foreman, Eucyrtidiellum sp. aff. nodosum Wakita, Homoeoparonaella argolidensis Baumgartner, Pantanellium whalenae Pessagno \& MacLeod, Pantanellium squinaboli (Tan), Parvicingula sp., Praeconocaryomma sp., Pseudictyomitra sp., Sethocapsa accincta Steiger, Sethocapsa horokanaiensis Kawabata, Sethocapsa sp., Stichocapsa sp., Vallupus hopsoni Pessagno \& Blome, Zhamoidellum ovum Dumitrica and Zhamoidellum sp.. This assemblage comprises some morphotypes previously documented by Matsuoka et al. [2002] and Gorican [1994] such as Sethocapsa accincta and S. horokanaiensis. It is also correlative with UAZ11 of Baumgartner et al. [1995] of late Kimmeridgian or early Tithonian age. However, the occurrence of Vallupus hopsoni (absent from Baumgartner et al. [1995]) would favor an early Tithonian age [Matsuoka, 1995] for this locality.

LDE27 (coordinates N16 $20^{\prime} 25.9^{\prime \prime}$ W61 00 '21.9”, no clear orientation) (fig. 3); $680 \mathrm{~m}$ to the north-northwest of the meteorological station; along shore, small outcrop of red chert within basalts. Radiolarians from this locality are badly preserved, with only Archeodictyomitra sp. being identified. It provides a Jurassic age without further precision.

LDE30 (coordinates N 16²0’11.5” W61 ${ }^{\circ} 00^{\prime} 15.9^{\prime}$ ) (fig. 3); $200 \mathrm{~m}$ from meteorological station, subexposure of red chert. Radiolarians are moderately well-preserved and comprise Angulobracchia sp., Eucyrtidiellum sp., Hsuum sp. aff. cuestaense Pessagno, Obesacapsula sp., Orbiculiformella sp., Paronaella spp., Parvicingula sp., Praeconocaryomma sp., Sethocapsa sp. cf. accincta Steiger, Sethocapsa sp. cf. horokanaiensis Kawabata, Tethysetta sp. cf. dhimenaensis (Baumgartner) and Williriedellum sp.. A tentative correlation for LDE30, which lacks well-preserved diagnostic morphotypes, would be with UAZ11 of Baumgartner et al. [1995] of late Kimmeridgian or early Tithonian age. 


\section{Age range of La Désirade cherts}

In summary, our results show that La Désirade cherts are Late Jurassic, ranging from late Kimmeridgian or early Tithonian to early or early late Tithonian. These localities do not carry identical faunal associations, neither do they all have the same age. Localities LDE7, LDE22 and LDE30 are assigned to biozone UAZ11 of Baumgartner et al. [1995] of late Kimmeridgian or early Tithonian age. The occurrence of Vallupus hopsoni at LDE22 would constrain this locality to the early Tithonian. LDE12 is assigned to the younger biozone UAZ12 of early of early late Tithonian age. This brings new and critical information to the knowledge of La Désirade Island geology, as previous studies by Bouysse et al. [1983], Montgomery et al. [1992] and Mattinson et al. [2008] considered chert exposures to be coeval (revised age: mid late Tithonian; see below).

\section{DISCUSSION AND INTERPRETATION}

\section{Previous radiolarian studies}

As mentioned earlier, Bouysse et al. [1983] considered their unit 2 to carry Early Cretaceous (Hauterivian-Barremian) radiolarians. Their single assemblage was wrongly assigned at the time to the Eucyrtis tenuis Zone of Foreman [1975], as shown by Montgomery et al. [1992] who documented radiolarians of Late Jurassic age at five localities (M3, M4, M6, TD and PM7 from their fig. 2). These assemblages were assigned to Subzone 4 beta or the lower part of Subzone 4 alpha of zonation from Pessagno et al. [1987] and Yang \& Pessagno [1989] of late early to mid late Tithonian age. Recently, Mattinson et al. [2008] documented again the original results of Montgomery et al. [1992] with one additional and coeval radiolarian locality from Pointe Frégule ("PF" from their fig. 5) and revised the original biochronological correlation of Montgomery et al. [1992] to the upper part of Subzone 4 beta of mid late Tithonian age. 
Several morphotypes reported by Montgomery et al. [1992] are present within Baumgartner et al. [1995] UA biozonation, which allows to compare biochronological assignments. Their best and most representative locality "M6" includes Acanthocircus sp. cf. dicranacanthos (UAZ10UAZ17), Eucyrtidiellum ptyctum (UAZ5-UAZ11), Loopus primitivus (UAZ7-UAZ12), Mirifusus baileyi (UAZ9-UAZ11) and Tritrabs ewingi (UAZ7-UAZ12), an assemblage which can be assigned to UAZ 10-11. Although Montgomery et al. [1992] and Mattinson et al. [2008] do not provide precise locality coordinates, their map suggests that M6 is located between our localities LDE22 and LDE30 which we assign to biozone UAZ11. Therefore the radiolarian assemblage reported by Montgomery et al. [1992] and Mattinson et al. [2008] would be equivalent to our oldest localities (LDE7, LDE22, LDE30) interpreted here as late Kimmeridgian or early Tithonian in age. Although we agree on the potential occurrence of late Tithonian radiolarians on the island, we believe that they come from a younger chert sequence not reported by previous authors (LDE12, fig. 3).

\section{Depositional environment}

La Désirade cherts have been previously considered as volcanic jaspers rather than radiolarian ribbon chert (RRC), based on spatial association with basalts as well as poor radiolarian recovery [Mattinson et al., 2008]. We propose here a different interpretation: the depositional environment of La Désirade cherts is probably a combination of factors comprising volcanicrelated hydrothermal jasper as well as slow radiolarian deposition generating ribbon chert sediments. This interpretation is based on the following observations: 1) true radiolarian ribbon chert do occur on the island, more particularly inland where we document our youngest radiolarian assemblage (LDE12); 2) as shown here, La Désirade chert deposition is not restricted to the mid late Tithonian as previously thought. Therefore, diachronous volcanic 
flows could have provided, after cooling, topographic basements for temporary planktonic deposition; 3) the quality of La Désirade radiolarians is not significantly different from that of typical ribbon cherts found for instance within Paleozoic and Mesozoic accretionary complexes [Cordey, 1998], as shown by the fair preservation of diagnostic morphological elements (see pl. 1, 2). In some cases, this may have been linked to the presence of volcanic-related silica-rich seawater [see discussions in De Wever et al., 1994; Racki \& Cordey, 2000].

\section{Paleobiogeographic affinities}

Previous paleobiogeographic analysis on radiolarian associations from La Désirade Island are confusing: Montgomery et al. [1992] assigned them to Northern Tethyan to Boreal paleolatitudes, whereas Mattinson et al. [2008] propose a Southern or Northern Tethyan affinity [sensu Pessagno et al., 1993]. According to Mattinson et al. [2008], all Upper Jurassic red cherts from the basement complexes of Puerto Rico, the Dominican Republic and Cuba have the same paleolatitudinal character. The presence of genus Vallupus has been used as a marker of paleolatitude by Matsuoka [1995b] who considers it characteristic of low and middle paleolatitudes (within $25^{\circ}$ of the Jurassic paleoequator). In combining these two models, the depocenters of La Désirade cherts could correspond to a fairly large ocean domain located at $\mathrm{N} 25^{\circ}-15^{\circ}$ or $\mathrm{S} 15^{\circ}-25^{\circ}$.

According to Baumgartner et al. [2004], radiolarians from La Désirade resemble coeval faunas extracted from cherts of the Californian Coast Range Ophiolite which they infer to have formed in the upwelling area along the Western American Margin. In their opinion, the presence of these faunas does not allow for a paleolatitudinal interpretation, but rather suggests a paleolongitudinal displacement from the Eastern Pacific and/or the western American Margin into their present position in Central America and the Eastern Caribbean. 
Our faunal associations partly differs in composition from those documented previously by Bouysse et al. [1983] and Mattinson et al. [2008], showing the difficulty of reliably identifying radiolarian faunal provincialism. At La Désirade, it is actually possible to come up with different conclusions depending on the studied localities. For instance, LDE12 bears a significant resemblance with Tethyan fauna and does not contain Vallupus which has been observed in all well-preserved samples from Mattinson et al. [2008], whereas LDE22 contains Parvicingula sp. and Vallupus sp. which are important components of Mattinson et al. [2008], and key elements on discussions by authors on paleogeography [Matsuoka, 1995b; Pessagno et al., 1993].

Although La Désirade Island and elements of the proto-Caribbean basement may have undergone significant displacements from the Eastern Pacific into the Caribbean region [Montgomery et al., 1994a, 1994b; Baumgartner et al., 2004], this interpretation may be more a result of consensual tectonic scenarios rather than a constrained model strictly based on paleobiogeography. Obviously, significant tectonic convergence occurred at the interaction between the Pacific and the Caribbean regions, but it doesn't necessarily imply that radiolarian depocenters had to be restricted to the Pacific realm. It was, after all, the same oceanic domain linking the Pacific to the Atlantic. Moreover, the absence of long-lived oceanic successions within the basement complexes of the lesser Antilles would tend to favour fairly restricted displacements of oceanic terranes prior to their entrapment in the Caribbean region. Similarly, Bortolotti \& Principi [2005] suggested that some Jurassic oceanic elements of the eastern border of the Greater and Lesser Antilles could have originated within the Central Atlantic oceanic realm. 


\section{Structure of La Désirade basement}

Our biochronological data suggest that the Northeast Complex is composed of basalt/chert successions of slightly different ages. In terms of spatial distribution, our oldest localities LDE7, LDE22 and LDE30 (late Kimmeridgian or early Tithonian) are found to the east of the complex whereas the youngest exposure LDE12 (early or early late Tithonian) is located to the west of the study area, showing an age polarity perpendicular to the fault structures exposed on the slope dipping eastward between Pointe Doublé and Pointe Mancenillier (fig. 3). Although the age coverage is far from being conclusive, these results suggest that the Northeast Complex may contain some structural stacking of low metamorphic grade. This is also supported by the occurrence of "chevron" folds and tectonic duplication within chert sequences on the eastern shore of the island. Therefore the Northeast Complex may have undergone an accretionary-type tectonic emplacement. This would be consistent with former interpretations that La Désirade eastern units corresponds to a basement complex trapped within the forearc of the Lesser Antilles in a subduction zone in the Mesozoic [Ghosh et al., 1984; Meschede \& Frisch, 1998]. The age distribution of chert localities shows a southeast to northwest-directed polarity from oldest to youngest exposures, which could be related to accretion within a former eastwarddirected subduction setting. Obviously this hypothesis must be considered with caution because we do not know the range of post-emplacement tectonics (rotations and/or overturns). However, this model may be tested in the event of future underwater dredging on the northern and eastern slopes of the island.

Until recently, it was unclear which was the oldest rock unit of La Désirade Island, which would also be the oldest unit of the entire Lesser Antilles region and the eastern part of the Caribbean plate. The new radiometric age of $143.74+/-0.33$ Ma recently produced by Mattinson et al. [2008] from the Trondhjemitic/Rhyolitic Igneous Complex (LDIC) would 
correspond to either late Tithonian [Palfy et al. , 2000] or early Berriasian [Gradstein et al., 2004]. If late Tithonian, this radiometric datum would partly overlap the youngest radiolarian assemblage, also of possibly late Tithonian age. Based on geological observations, Mattinson et al. [2008] favoured the interpretation that the basalt/chert association of the Northeast Complex is older that the Igneous Complex (LDIC). Our results not only support this view but also provide a clearer understanding of the age relationships among these units, as our oldest radiolarian assemblages (biozone UAZ11) are probably no younger than early Tithonian. Therefore the chert/basalt association of the Northeast Complex is, so far as known, the oldest unit of La Désirade Island, the Lesser Antilles region, and the eastern part of the Caribbean plate.

\section{Bearing on the evolution of the Lesser Antilles and the Caribbean plate}

As stated in the Introduction, the actual nature of the basement complex of La Désirade Island has been much debated and no final model has yet been established. The "ophiolitic complex" [Mattinson et al., 1973, 1980; Fox \& Heezen, 1975; Dinkelman \& Brown, 1977, Le Guen de Kerneizon et al., 1979] has also been interpreted as a primitive island arc detached from the Greater Antilles [Fink, 1968, 1970a, 1970b, 1972; Bouysse et al., 1983; Maury et al., 1990; Donnelly et al., 1990]. A more recent study by Gauchat [2004] suggests that La Désirade pillow basalts have a back-arc geochemichal signature. Baumgartner et al. [2004] stressed that Caribbean radiolarites are associated with mafic and ultramafic igneous rocks of diverse petrogenetic origins, but rarely do they form the stratigraphic cover of MORB-type ocean floor. Although Mattinson \& Hopson [in Mattinson et al., 2008] stand by their original conclusion that the igneous rock assemblage and vertical distribution on La Désirade are compatible with the upper part of an ophiolite, we do not support this interpretation. In our opinion, La Désirade oceanic rocks display a peculiar spatial combination of volcanics and oceanic deposits 
illustrating an interaction of arc-related material and siliceous biogenous sedimentation. This is consistent with the depth of deposition assessed by Bouysse et al. [1983] who analyzed the Grand Abaque eruptive center and its submarine scoriae, proposing a maximum lower limit of about $2000 \mathrm{~m}$ based on the equilibrium between hydrostatic and critical water pressures.

\section{CONCLUSION}

Our investigation of La Désirade Island basement complex brings the following results and interpretations:

1) Radiolarian fauna obtained from seven chert localities range in age from late Kimmeridgian-early Tithonian to early or early late Tithonian. It confirms the occurrence of Late Jurassic oceanic strata associated with volcanics of the basement complex. The basalt/chert unit is the oldest on the island, therefore of the entire Lesser Antilles region.

2) Whereas former studies reported a single radiolarian age datum on the island, we show that some chert localities are diachronous. La Désirade Jurassic volcanism probably lasted over a longer period than previously established.

3) The spatial association of radiolarian-bearing cherts and volcanics does not favour the model of an ophiolite-type oceanic crust, but rather the occurrence of arc-related submarine volcanic activity combined with planktonic sedimentation.

4) Tectonic stacking suggested by biostratigraphic data could be linked to an accretiontype tectonic emplacement. The preliminary age distribution provided by chert localities shows a southeast to northwest-directed polarity, potentially indicative of a former eastward subduction zone in the eastern part of the proto-Caribbean plate. This tentative model needs to be tested by future tectonic studies in the region. 


\section{ACKNOWLEDGEMENTS}

We thank Auran Randrianasolo, Jean-Frédéric Lebrun, Jean-Len Léticée (Université AntillesGuyane, Pointe-à-Pitre), and Henry Pariselle (La Désirade) for their logistical help in Guadeloupe. Funding was provided by the INSU-DyETI program as well as the Institut Universitaire de France (Christophe Lécuyer, CNRS-UMR 5125). Michael J. Orchard (Geological Survey of Canada) and John Buckton (Lyon) improved our original manuscript. Špela Goričan (University of Ljubljana) and Peter Baumgartner (University of Lausanne) provided thorough and insightful reviews. We thank Nadine Morel and Christine Salsa for their support in St-François (Grande-Terre). Chief pilot Luc Beuzelin (Alpha Aviation, St-François) flew us around La Désirade Island and helped to improve our detection of chert localities. Arlette Armand and Paula Desvignes (UMR 5125) provided technical and SEM help at the University of Lyon. 


\section{REFERENCES}

BAUMGARTNER P.O., BARTOLINI A., CARTER E.S., CONTI M., CORTESE G., DANELIAN T., DE WEVER P., DUMITRICÀ P., DUMITRICÀ-JUD R., GORIČAN S., GUEX J., HULL D.M., KITO N., MARCUCCI M., MATSUOKA A., MURCHEY B., O’DOGHERTY L., SAVARY J., VISHNEVSKAYA V., WIDZ D. \& YAO A. (1995). Middle Jurassic to Early Cretaceous radiolarian biochronology of Tethys based on Unitary Associations. In: BAUMGARTNER P. O. et al., Eds., Middle Jurassic to Lower Cretaceous Radiolaria of Tethys : occurrences, systematics, biochronology, Mém. Géol., Lausanne, 23, $1013-1048$.

BAUMGARTNER P.O., BANDINI A. \& DENYER P. (2004). - Jurassic-Lower Cretaceous radiolarites in Central America and the Caribbean - remnants of Pacific ocean floor, Second Swiss Geosc. Meeting Abs., Lausanne, 1-2.

BORTOLOTTI V. \& PRINCIPI G. (2005). - Tethyan ophiolites and Pangea break-up. The Island Arc, 14, 442-470.

BOUYSSE P., SCHMIDT-EFFING R. \& WESTERCAMP D. (1983). - La Desirade Island (Lesser Antilles) revisited: Lower Cretaceous radiolarian cherts and arguments against an ophiolitic origin for the basal complex, Geology, 11, 244-247.

CHIARI M., CORTESE G., MARCUCCI M. \& NOZZOLI N. (1997). - Radiolarian biostratigraphy in the sedimentary cover of the ophiolites of south-western Tuscany, Central Italy, Eclogae geol. Helv., 90, 55-77. 
CORDEY F. (1998). - Radiolaires des complexes d'accrétion cordillérains, Geol. Surv. Canada Bull., 509, 210 p.

CORDEY F. \& KRAUSS P. (1990). - A field technique for identifying and dating radiolaria applied to British Columbia and Yukon, Geol. Survey Canada Paper 90-1E, 127-129.

DE WEVER P., AZEMA J. \& FOURCADE E. (1994). - Radiolaires et radiolarites: production primaire, diagénèse et paléogéographie. Bulletin Centre Recherche Exploration-Production Elf Aquitaine, 18, 315-379.

DINKELMAN M. G. \& BROWN J. F. (1977). - K-Ar geochronology and its significance to the geologic setting of La Desirade (Lesser Antilles), Caribbean Geol. Conf., 8th, Curacoa, Abstracts, 38-39.

DONNELLY T. W., BEETS D., CARR M. J., JACKSON T., KLAVER G., LEWIS J., MAURY R., SCHELLENKENS H., SMITH A. L., WADGE G. \& WESTERCAMP D. (1990). - History and tectonic setting of Caribbean magmatism. In: DENGO G. \& CASE J. E., Eds., The Caribbean region, Boulder, Colorado, Geological Society of America, The Geology of North America, H, 339-350.

FINK L. K. JR. (1968). - Marine geology of the Guadeloupe region, Lesser Antilles arc, Ph.D. thesis, Miami University, Florida, $121 \mathrm{p}$. 
FINK L. K. JR. (1970a). - Evidence for the antiquity of the Lesser Antilles island arc, EOS, American Geophys. Union Trans., 51, 326-327.

FINK L. K. JR. (1970b). - Field guide to the island of La Desirade with notes on the regional history and development of the Lesser Antilles island arc, International field guidebook to the Caribbean island arc system, American Geol. Instit. andNat. Sc. Found., 17 p.

FINK L. K. JR. (1972). - Bathymetric and geologic studies of the Guadeloupe region, Lesser Antilles Island Arc. Marine Geol., 12, 267-288.

FOREMAN H. P. (1975). - Radiolaria from the North Pacific. In: LARSON R. L., MOBERLEY R. et al., Eds., Initial reports of the Deep Sea Drilling Project, Leg 32, U.S. Government Printing Office, 579-676.

FOX P. J. \& HEEZEN B. C. (1975). - Geology of the Caribbean crust. In: NAIRN E. M. \& STEHLI F.G., Eds, The ocean basins and margins, New York, Plenum Press, 3, pp. 421-466.

GAUCHAT K. (2004). - Geochemistry of Desirade Islands rocks (Guadeloupe, French Antilles). Unpub. diploma thesis, University of Lausanne, $80 \mathrm{p}$.

GHOSH N., HALL S. A. \& CASEY J. F. (1984). - Seafloor spreading magnetic anomalies in the Venezuelan Basin. In: BONINI W., HARGRAVES R.B., \& SHAGAM R., Eds., The Caribbean-South American Plate Boundary and Regional Tectonics, GSA Memoir, 162, 65-80. 
GORICAN S. (1994). - Jurassic and Cretaceous radiolarian biostratigraphy and sedimentary evolution of the Budva Zone (Dinarides, Montenegro), Mém. Géol., Lausanne, 18, 178 p.

GRADSTEIN F.M., OGG J.G., SMITH A.G. et al. (2004). - A Geologic Time Scale, Cambridge Univ. Press, Cambridge, 589 p.

HORI N. (1999). - Latest Jurassic radiolarians from the northeastern part of the Torinoko Block, Yamizo Mountains, central Japan. Sc. Reports of Instit. Geosc., Univ. Tsukuba, 20, 47114.

LE GUEN DE KERNEIZON M., MASCLE A., MAURY R.C. \& WESTERCAMP D. (1979). - Les laves de La Désirade (Petites Antilles), témoins d'un magmatisme de marge active : arguments minéralogiques, Bureau Rech. Géol. Min. Bull., Orléans, IV, n. 3/4, 285-292.

MATSUOKA A. (1995a). - Jurassic and Lower Cretaceous radiolarian zonation in Japan and in the western Pacific, The Island Arc, 4, 140-153.

MATSUOKA A. (1995b). - Late Jurassic tropical Radiolaria : Vallupus and its related forms, Palaeogeog. Palaeoclimatol. Palaeoecol., 119, 359-369.

MATSUOKA A., YANG Q., KOBAYASHI K., TAKEI M., NAGAHASHI T., ZENG Q. \& WANG Y. (2002). - Jurassic-Cretaceous radiolarian biostratigraphy and sedimentary environments of the Ceno-Tethys: records from the Xialu Chert in the Yarlung-Zangbo Suture Zone, southern Tibet, J. Asian Earth Sc., 20, 277-287. 
MATSUOKA A., YANG Q. \& TAKEI M. (2005). - Latest Jurassic--earliest Cretaceous radiolarian fauna from the Xialu chert in the Yarlung Zangbo suture zone, southern Tibet: comparison with coeval western Pacific radiolarian faunas and paleoceanographic implications, The Island Arc, 14, 338-345.

MATTINSON J. M., FINK L. K. JR. \& HOPSON C. A. (1973). - Age and origin of ophiolitic rocks on La Desirade Island, Lesser Antilles island arc, Carnegie Instit. Washington Yearbook, 72, 616-623.

MATTINSON J. M., FINK L. K. JR. \& HOPSON C. A. (1980). - Geochronologic and isotopic study of the La Desirade Island basement complex. Jurassic oceanic crust in the Lesser Antilles. Contrib. Mineral. Petrol., 71, 237-245.

MATTINSON J. M., PESSAGNO E.A. JR., MONTGOMERY H. \& HOPSON C.A. (2008). Late Jurassic age of oceanic basement at La Désirade Island, Lesser Antilles arc. In: WRIGHT J. \& SHERVAIS J., Eds., Ophiolites, arcs, and batholiths: a tribute to Cliff Hopson, GSA Spec. Paper, 438, 175-190.

MAURY R. C., WESTBROOK G. K., BAKER P. E., BOUYSSE P. \& WESTERCAMP D. (1990). - Geology of the Lesser Antilles. In: DENGO G. \& CASE J. E., Eds., The Caribbean region, Boulder, Colorado, Geological Society of America, The Geology of North America, H, $141-166$.

MESCHEDE M. \& FRISCH W. (1998). - A plate-tectonic model for the Mesozoic and Early Cenozoic history of the Caribbean plate, Tectonophysics, 296, 269-291. 
MONTGOMERY H., PESSAGNO E. A. JR. \& MUNOZ I. (1992). - Jurassic (Tithonian) Radiolaria from La Desirade (Lesser Antilles): Preliminary paleontological and tectonic implications, Tectonics, 11, 1426-1432.

MONTGOMERY H., PESSAGNO E. A. JR. \& PINDELL J. L. (1994a). - A 195 Ma terrane in a 165 Ma sea; Pacific origin of the Caribbean Plate, Geol. Today, 4, 3-6.

MONTGOMERY H., PESSAGNO E. A. JR., LEWIS J. F. \& SCHELLEKENS J. (1994b). Paleogeography of Jurassic fragments in the Caribbean, Tectonics, 13, 725-732.

PÁLFy J., SMITH P. L. \& MORTENSEN J. K. (2000). - A U-Pb and ${ }^{40} \mathrm{Ar} /{ }^{39} \mathrm{Ar}$ time scale for the Jurassic, Can. J. Earth Sc., 37, 923-944.

PESSAGNO E.A. JR., BLOME C. D. \& LONGORIA J. F. (1984). - A revised radiolarian zonation for the Upper Jurassic of western North America, Bull. Amer. Paleont., 87, 5-51.

PESSAGNO E. A. JR., LONGORIA J. F., MACLEOD N. \& SIX W. M. (1987). - Upper Jurassic (Kimmeridgian-upper Tithonian) Pantanelliidae from the Taman Formation, eastcentral Mexico: tectonostratigraphic, chronostratigraphic, and phylogenetic implications, Cushman Found. Foram. Res. Spec. Pub., 23, 1-51.

PESSAGNO E. A. JR., BLOME C. D., HULL D. \& SIX W. M. (1993). - Middle and Upper Jurassic Radiolaria from the Western Klamath terrane, Smith River subterrane, northwestern 
California: their biostratigraphic, chronostratigraphic, geochronologic, and paleolatitudinal significance. Micropaleontology, 39, 93-166.

RACKI G. \& CORDEY F. (2000). - Radiolarian paleoecology and radiolarites: is the present the key to the past? Earth Sc. Rev., 52, 83-120.

WESTERCAMP D. (1980). - La Désirade, carte géologique à 1:25 000 et notice explicative. Service géologique national, Bur. Rech. Géol. Min., Orléans, France.

YANG, Q. \& PESSAGNO E. A. JR. (1989). - Upper Tithonian Vallupinae (Radiolaria) from the Taman Formation, east-central Mexico. Micropaleontology, 35, 114-134. 


\section{FIGURE CAPTIONS}

Figure 1. Structural map of the Caribbean region and the Lesser Antilles arc with location of the Guadeloupe archipelago.

Figure 1. Schéma structural de la region Caraïbes et de l'arc des Petites Antilles, et localisation de l'archipel de Guadeloupe.

Figure 2. a: The Lesser Antilles arc and the location of La Désirade Island; b: geological sketch map of La Désirade [after Westercamp, 1980].

Figure 2. a: Localisation de l'île de La Désirade dans l'arc des Petites Antilles; b: carte géologique simplifiée de La Désirade [d'après Westercamp, 1980].

Figure 3. Geological map of the Northeast Complex unit of La Désirade Island, location of radiolarian-bearing localities LDE1 to LDE30 and biochronological assignments [UAZ: Unitary Association biozones, Baumgartner et al. 1995].

Figure 3. Carte géologique de l'unité du Complexe de Base du Nord-Est de La Désirade, localités à radiolaires LDE1 to LDE30 et corrélations biochronologiques [UAZ: biozones d’Associations Unitaires, Baumgartner et al. 1995].

Figure 4. Exposures of sedimentary successions and associated magmatic units from La Désirade "Northeast Volcanic complex". a: basaltic flows overlying red and brown chert and tuffs at Pointe Mancenillier; b: pillow basalts overlying a thin red chert sequence at Pointe Doublé; c: close-up of chert sequence; d: cross-section of large pillow basalt or flow with interpillow red chert (to right hand side of hammer), north of Pointe Mancenillier; e, f: pillow basalts into red chert sequence near Pointe Doublé; g: contact between basaltic pillows and 
overlying red chert and hyaloclastites, north of Pointe Mancenillier; h: interbedded red chert (dark colour) and graded bedded tuffs (light colour), west of Baie Mahault.

Figure 4. Roches sédimentaires et magmatiques du complexe de base de La Désirade. a: coulées basaltiques recouvrant des jaspes rouges et bruns ainsi que des tuffs, Pointe Mancenillier; b: basaltes en coussins recouvrant une série peu épaisses de jaspes rouges, Pointe Doublé; c: vue rapprochée d'un niveau de jaspes; d: section de coulée basaltique comprenant de larges coussins et des méas de jaspe rouge à radiolaires (à droite du marteau), nord de la Pointe Mancenillier; e, f: coussin basaltique dans une série de jaspes à radiolaires près de la Pointe Doublé; g: contact entre des coussins basaltiques et des jaspes rouges et hyaloclastites, nord de la Pointe Mancenillier; h: interstratification de jaspes rouges et de tuffs granoclassés, ouest de Baie Mahault.

\section{TABLE CAPTION}

Table 1. List of radiolarian taxa and occurrences from La Désirade cherts. LDE3 to LDE30 are productive localities (see text for location); bottom: correlation with UA biozonation from Baumgartner et al. [1995] (n.a.: not available).

Table 1. Liste des taxons de radiolaires de La Désirade et leur occurrence. LDE3 à LDE30 correspondent aux localités diagnostiques (voir texte) ; base : corrélation aux biozones d'Associations Unitaires de Baumgartner et al. [1995] (n.a.: néant). 


\section{PLATE CAPTIONS}

Plate 1. Late Jurassic radiolarians from La Désirade cherts (Scanning Electron Microscope).

Figures: taxon, sample number, database picture number, maximum width.

Planche 1. Radiolaires du Jurassique supérieur de La Désirade (Microscope Electronique à Balayage). Figures : taxon, numéro d'échantillon, numéro de cliché de la base de données («px »), largeur maximale.

1. Loopus sp., LDE12, p10, 345 m; 2-3. Pseudodictyomitra spp., LDE12, 3, $520 \mu \mathrm{m} ; \mathrm{p} 4,420$ $\mu \mathrm{m} ;$ 4. Pseudodictyomitra carpatica (Lozyniak) LDE12, p5, $380 \mu \mathrm{m}$; 5. Loopus primitivus (Matsuoka \& Yao), LDE12, p6, $330 \mu \mathrm{m} ; 6$. Archaeodictyomitra excellens (Tan), LDE9, p5, $385 \mu \mathrm{m}$; 7. Tethysetta sp. cf. dhimenaensis, LDE30, p7, $430 \mu \mathrm{m}$; 8. Archaeodictyomitra sp., LDE12, p13, 365 m; 9. Thanarla sp., LDE12, p11, $360 \mu$ m; 10. Loopus sp., LDE12, p18, 365 $\mu \mathrm{m}$; 11. Xitus gifuensis Mizutani, LDE12, p8, $460 \mu \mathrm{m}$; 12. Sethocapsa accincta Steiger, LDE22, p19, $410 \mu \mathrm{m} ; 13-14$. Sethocapsa sp., LDE22, p17, $375 \mu \mathrm{m} ; \mathrm{p} 24,345 \mu \mathrm{m} ; 15$.

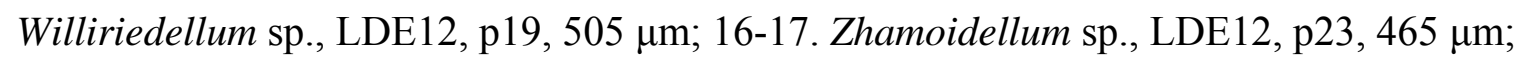
LDE22, p15, $400 \mu \mathrm{m}$; 18. Zhamoidellum sp. aff. ovum Dumitrica, LDE12, p20, $395 \mu \mathrm{m}$.

Plate 2. Late Jurassic radiolarians from La Désirade cherts (Scanning Electron Microscope). Figures: taxon, sample number, database picture number, maximum width.

Planche 2. Radiolaires du Jurassique supérieur de La Désirade (Microscope Electronique à Balayage). Figures : taxon, numéro d'échantillon, numéro de cliché de la base de données (« px »), largeur maximale.

1. Praeconocaryomma sp., LDE22, p1, $745 \mu \mathrm{m} ; 2$-3. Vallupus hopsoni Pessagno \& Blome, LDE22, p11, $370 \mu \mathrm{m} ; \mathrm{p} 12,310 \mu \mathrm{m} ; 4$. Pantanellium whalenae Pessagno \& MacLeod, LDE22, p21, $365 \mu \mathrm{m}$; 5. Pantanellium squinaboli (Tan), LDE22, p22, $290 \mu \mathrm{m}$; 6-7. Paronaella spp., LDE30, p5, $1200 \mu \mathrm{m} ;$ p4, $1200 \mu \mathrm{m} ; 8$. Angulobracchia sp., LDE30, p6, $1250 \mu \mathrm{m} ; 9$. 
Eucyrtidiellum ptyctum (Riedel \& Sanfilippo), LDE7, p5, $120 \mu \mathrm{m}$ 10. Eucyrtidiellum pyramis Aita, LDE12, p14, $200 \mu \mathrm{m}$; 11. Pseudodictyomitrella sp. aff. tuscanica (Chiari, Cortese \& Marcucci), LDE12, p2, $550 \mu \mathrm{m} ; 1$ 12. Obesacapsula sp. cf. verbana (Parona), LDE30, p3, 1100 $\mu \mathrm{m}$; 13. Parvicingula sp., LDE22, p25, $385 \mu \mathrm{m} ; 14$. Hsuum sp. aff. cuestaense Pessagno, LDE30, p11, 470 m; 15. ?Eucyrtidiellum sp., LDE12, p22, $400 \mu \mathrm{m}$; 16. ?Sethocapsa sp., LDE22, p3, $580 \mu \mathrm{m} ; 17$. Zhamoidellum sp., LDE12, p17, $375 \mu \mathrm{m}$. 


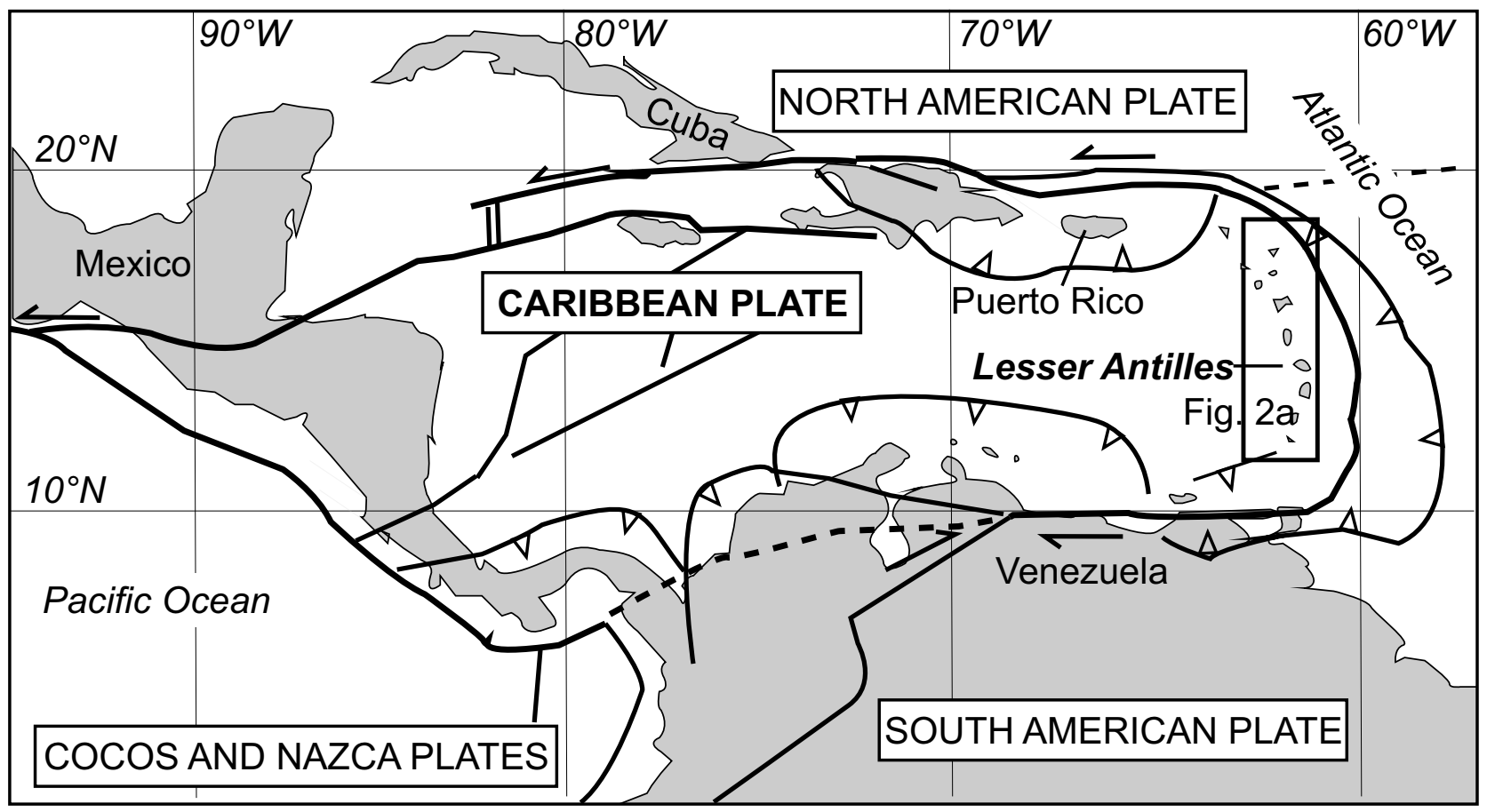

Cordey \& Cornée, Fig. 1 


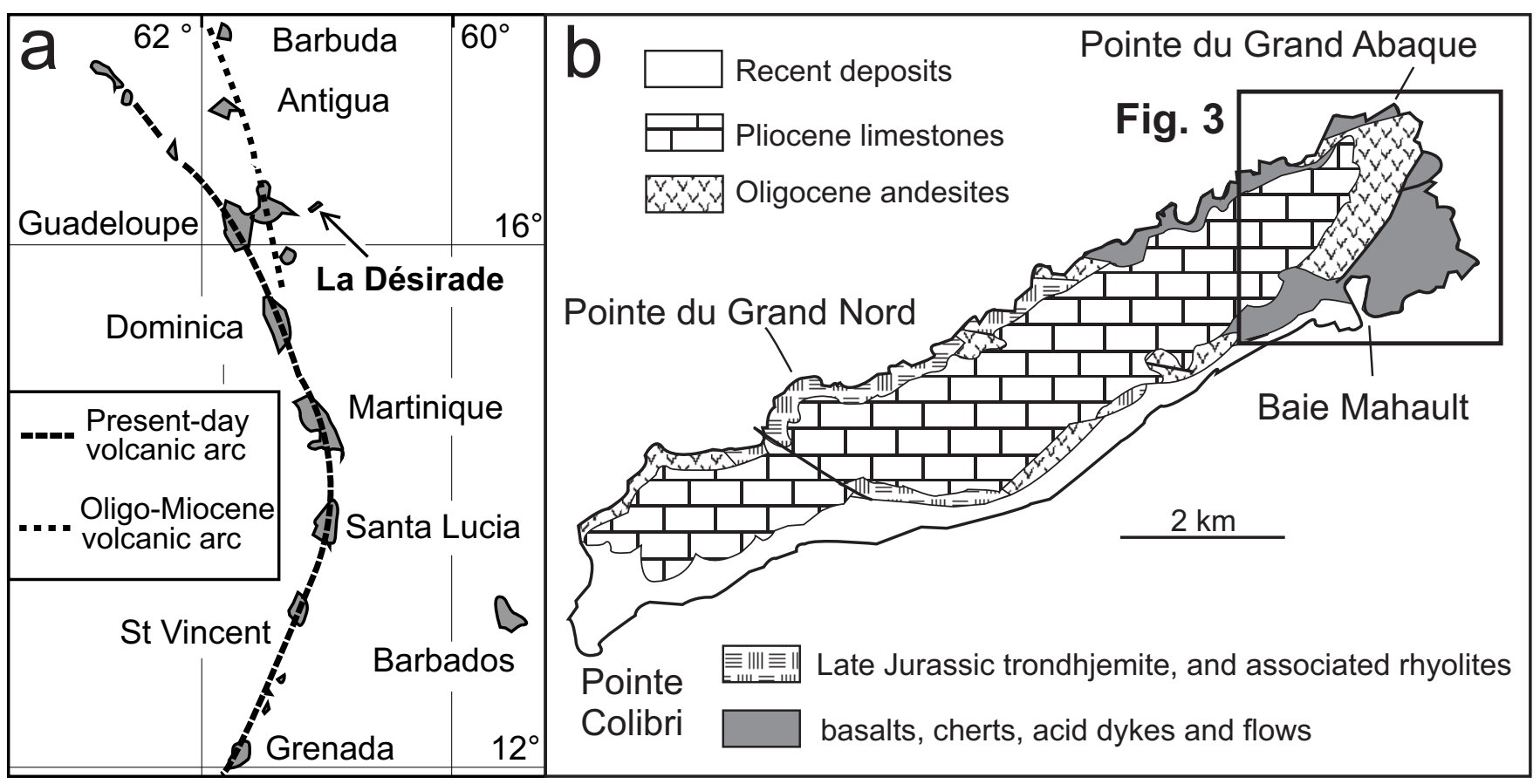

Cordey \& Cornée, Fig. 2 


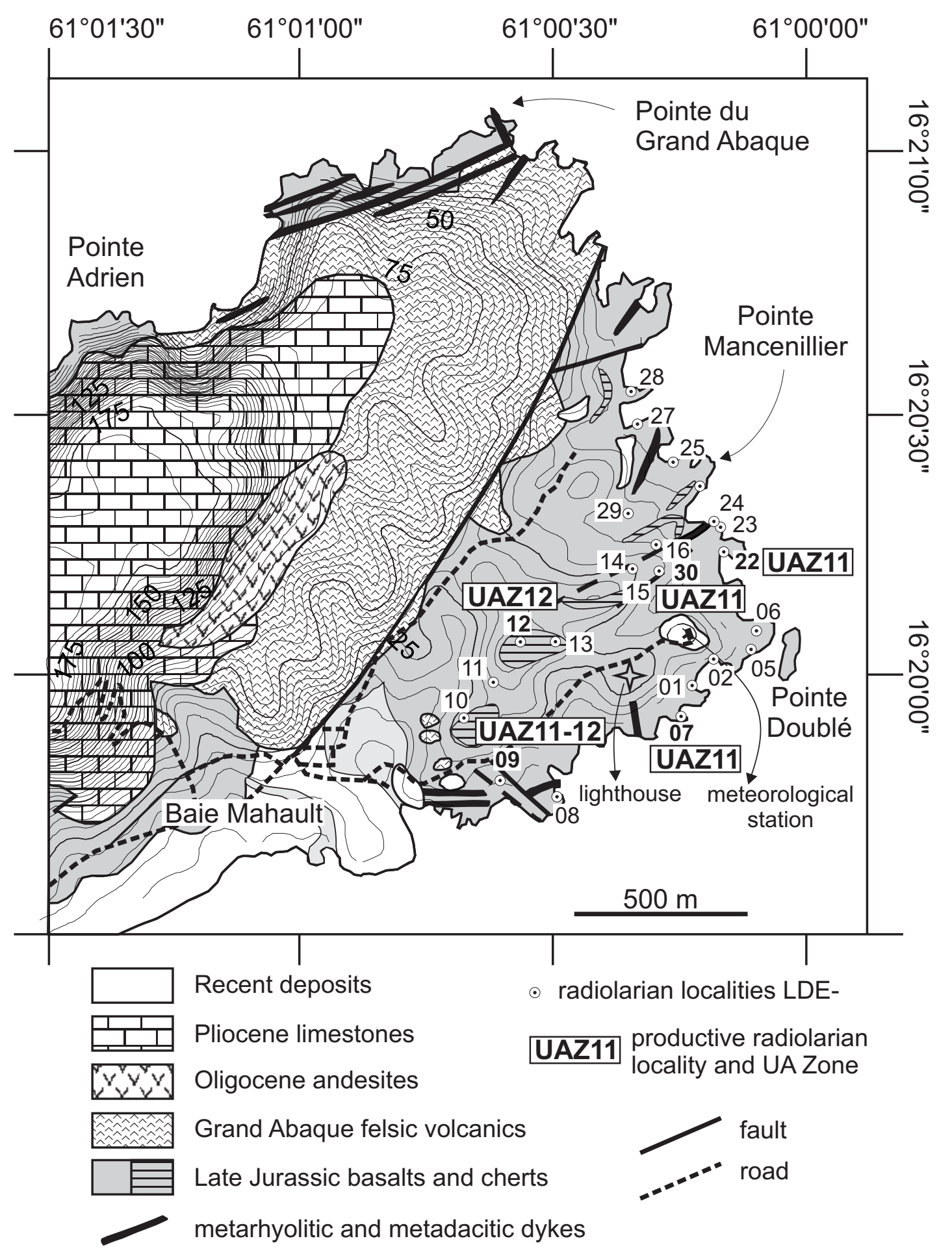

Cordey \& Cornée, Fig. 3 

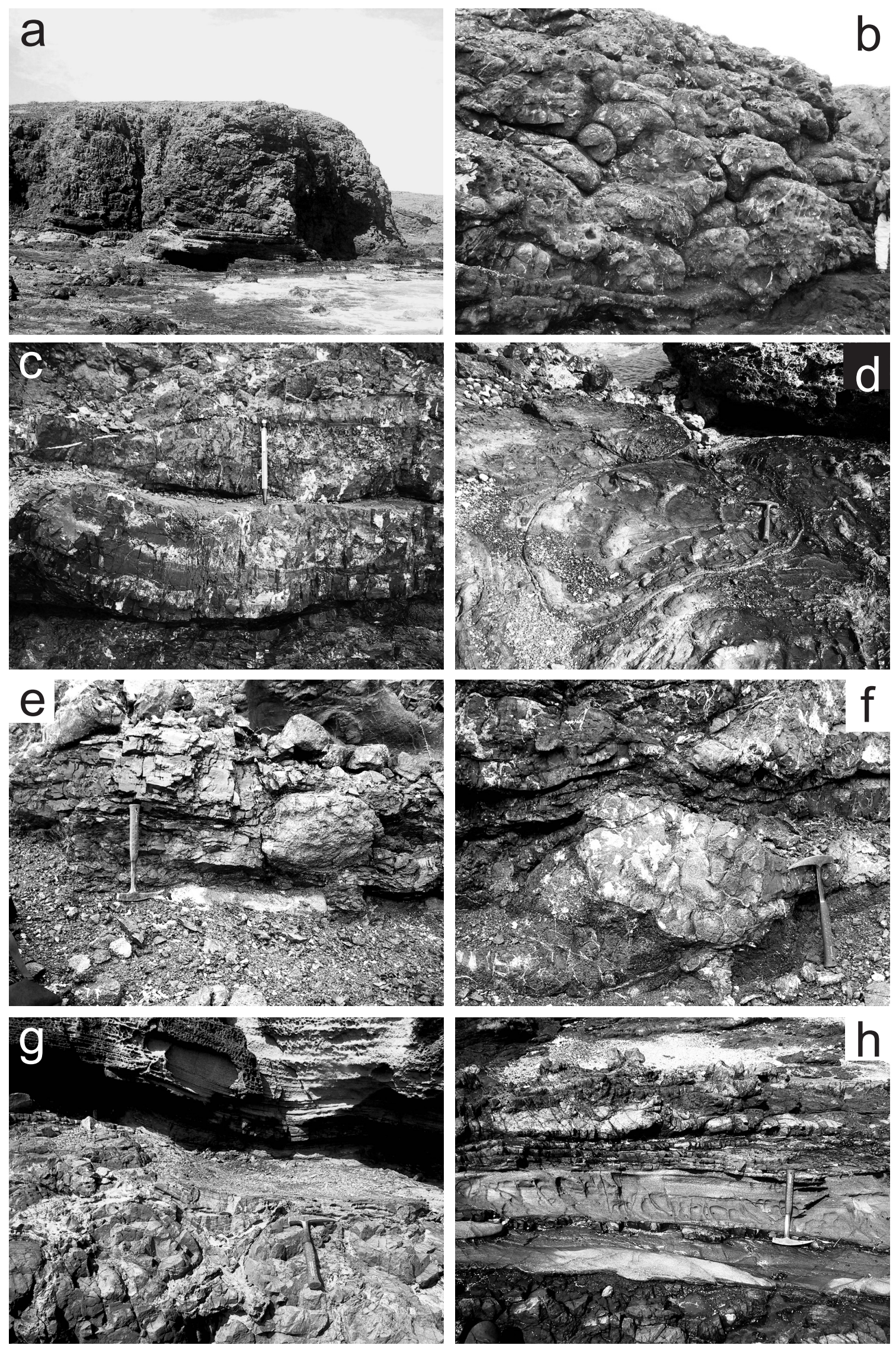

Cordey \& Cornée, Fig. 4 


\begin{tabular}{|c|c|c|c|c|c|c|c|}
\hline Radiolarian taxa & LDE3 & LDE7 & LDE9 & LDE12 & LDE22 & LDE27 & LDE30 \\
\hline Angulobracchia sp. & & & & & & & $\mathrm{X}$ \\
\hline Archaeodictyomitra excellens (Tan) 11-22 & & & $\mathrm{X}$ & & & & \\
\hline Archaedictyomitra sp. aff. excellens (Tan) & & & & $\mathrm{X}$ & & & \\
\hline Archaeodictyomitra minoensis (Mizutani) 9-12 & & & $\mathrm{X}$ & $\bar{X}$ & & & \\
\hline Archaeodictyomitra sp. & & & & $\mathrm{X}$ & & $\mathrm{X}$ & \\
\hline Emiluvia chica Foreman 3-18 & & & & & $\mathrm{x}$ & & \\
\hline Emiluvia sp. cf. salensis Foreman 4-13 & & & & $\mathrm{X}$ & & & \\
\hline Eucyrtidiellum sp. aff. nodosum Wakita & & & & & $\mathrm{X}$ & & \\
\hline Eucyrtidiellum ptyctum (Riedel \& Sanfilippo) 5-11 & & $\mathrm{X}$ & & & & & \\
\hline Eucyrtidiellum pyramis (Aita) 12-13 & & & & $\mathrm{X}$ & & & \\
\hline Eucyrtidiellum sp. & & & $\mathrm{X}$ & & & & $\mathrm{X}$ \\
\hline Homoeoparonaella argolidensis Baumgartner 4-11 & & & & & $\mathrm{X}$ & & \\
\hline Hsuum sp. aff. cuestaense Pessagno 10-13 & & & & & & & $\mathrm{X}$ \\
\hline Loopus primitivus (Matsuoka \& Yao) 7-12 & & & $\mathrm{X}$ & $\mathrm{X}$ & & & \\
\hline Obesacapsula verbana (Parona) 11-20 & & $\mathrm{X}$ & & & & & \\
\hline Obesacapsula sp. & & & & & & & $\mathrm{X}$ \\
\hline Orbiculiformella sp. & & & & & & & $\mathrm{X}$ \\
\hline Pantanellium whalenae Pessagno \& MacLeod & & & & & $\mathrm{X}$ & & \\
\hline Pantanellium squinaboli (Tan) 11-22 & & & & & $\mathrm{X}$ & & \\
\hline Paronaella spp. & & & & & & & $\mathrm{X}$ \\
\hline Parvicingula sp. & & & & & $\mathrm{X}$ & & $\mathrm{X}$ \\
\hline Praeconocaryomma spp. & & $\mathrm{X}$ & & & $\mathrm{X}$ & & $\mathrm{X}$ \\
\hline Pseudodictyomitra carpatica (Lozynyak) 11-21 & & & $\mathrm{X}$ & $\mathrm{X}$ & & & \\
\hline Pseudodictyomitra sp. & & & & $\bar{X}$ & $\mathrm{X}$ & & \\
\hline Pseudodict. sp. aff. tuscanica (Chiari, Cortese \& Marcucci) & & & & $\bar{X}$ & & & \\
\hline Sethocapsa accincta Steiger & & & & & $\bar{X}$ & & \\
\hline Sethocapsa sp. cf. accincta Steiger & & & & & & & $\mathrm{X}$ \\
\hline Sethocapsa horokanaiensis Kawabata & & & & & $\mathrm{X}$ & & \\
\hline Sethocapsa sp. cf. horokanaiensis Kawabata & & & & & & & $\mathrm{X}$ \\
\hline Sethocapsa sp. & & & & $\mathrm{X}$ & $\mathrm{x}$ & & \\
\hline Stichocapsa sp. & & & & $\mathrm{X}$ & $\mathrm{X}$ & & \\
\hline ?Stylocapsa sp. & & & & $\mathrm{X}$ & & & \\
\hline Tethysetta sp. cf. dhimenaensis (Baumgartner) 3-11 & & & & & & & $\mathrm{X}$ \\
\hline Thanarla sp. & & & & $\mathrm{X}$ & & & \\
\hline Vallupus hopsoni Pessagno \& Blome & & & & & $\mathrm{X}$ & & \\
\hline Vallupus sp. & $\mathrm{X}$ & & & & & & \\
\hline Williriedellum sp. & & & & $\mathrm{X}$ & & & $\mathrm{X}$ \\
\hline Xitus gifuensis Mizutani 11-18 & & & & $\bar{X}$ & & & \\
\hline Zhamoidellum ovum Dumitrica 9-11 & & & & & $\bar{X}$ & & \\
\hline Zhamoidellum sp. aff. ovum Dumitrica & & & & $\bar{X}$ & & & \\
\hline Zhamoidellum sp. & & & & $\mathrm{X}$ & $\mathrm{X}$ & & \\
\hline Unitary Association Zones & n.c. & 11 & 11-12 & 12 & 11 & n.c. & 11 \\
\hline
\end{tabular}

Cordey \& Cornée Table 1 

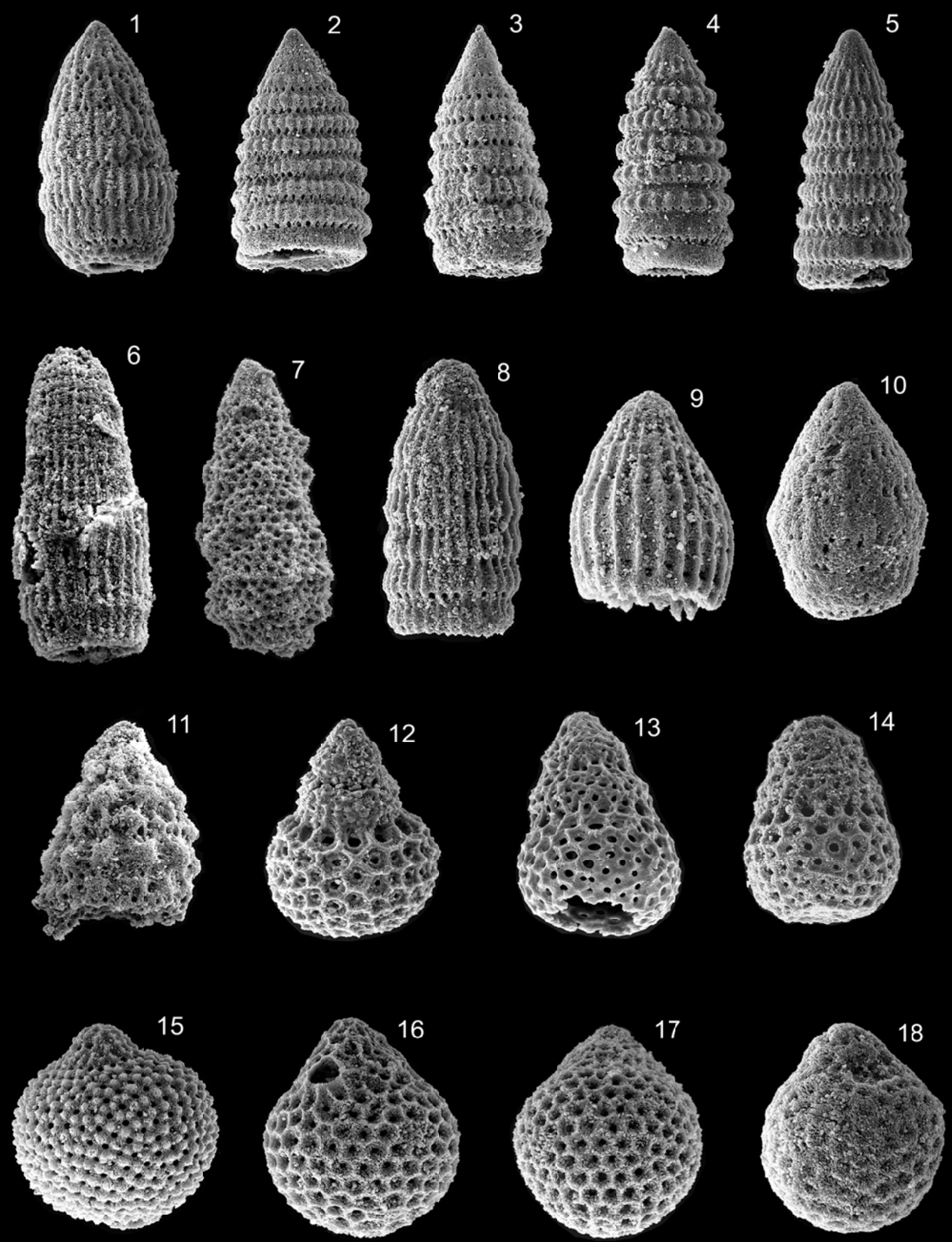

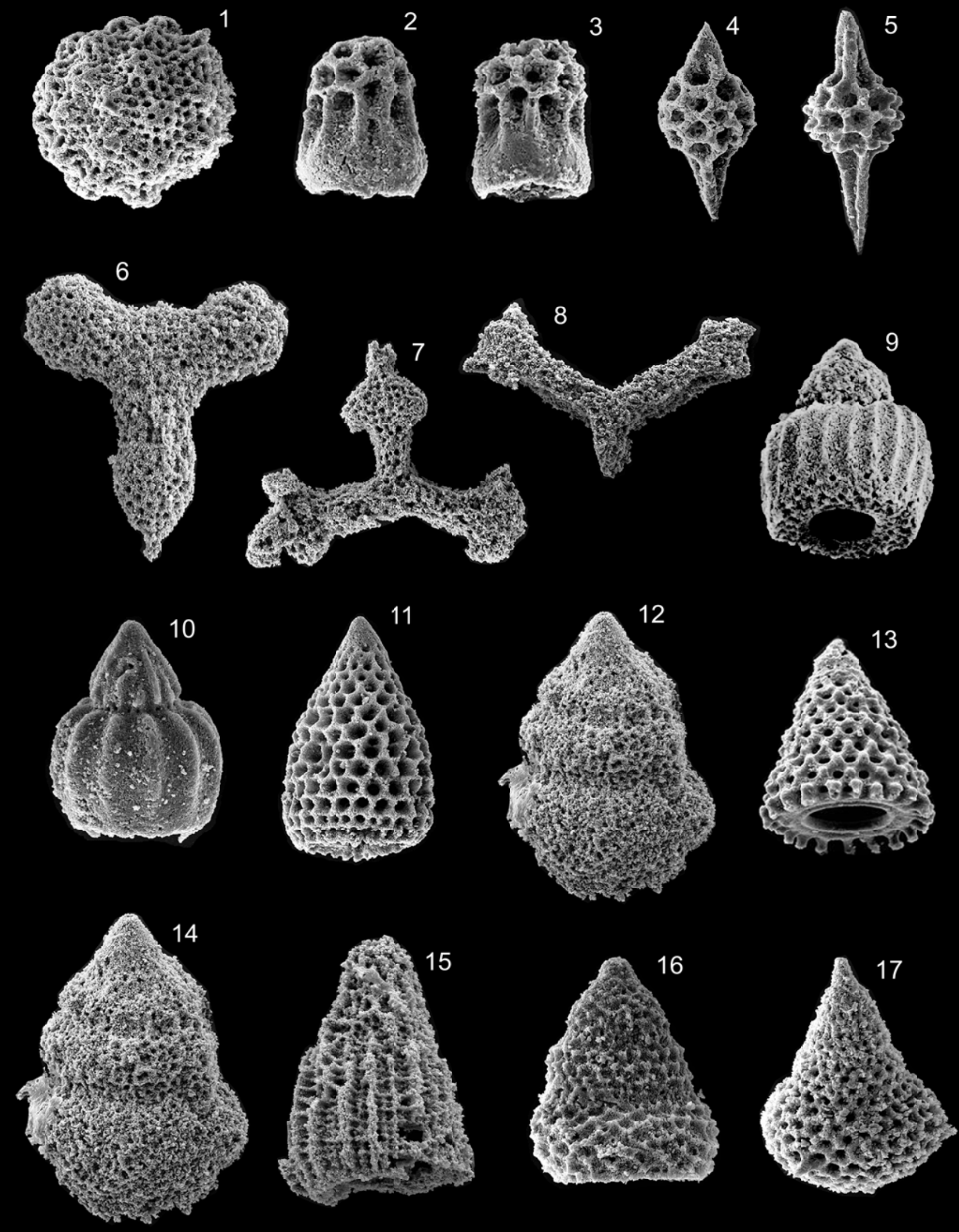